\title{
PENGELOLAAN KEUANGAN PESANTREN
}

\author{
Aep Tata Suryana \\ Universitas Islam Negeri Sunan Gunung Djati Bandung, Indonesia \\ Email: aeptatasurya@uinsgd.ac.id
}

\begin{abstract}
Abstrak
Tujuan penelitian adalah untuk mengetahui gambaran pengelolaan keuangan pesantren. Sesuai dengan judul peneltian,maka penelitian menggunakan metode kepustakaan. Hasil penelitian menjelaskan bahwa Manajemen keuangan merupakan tindakan pengurusan/ ketatausahaan keuangan yang meliputi pencatatan, perencanaan, pelaksanaan, pertanggungjawaban dan pelaporan. Dengan demikian, manajemen keuangan sekolah dapat diartikan sebagai rangkaian aktivitas mengatur keuangan sekolah mulai dari perencanaan, pembukuan, pembelanjaan, pengawasan dan pertanggungjawaban keuangan sekolah. Manajemen keuangan pondok pesantren merupakan salah satu substansi manajamen lembaga pendidikan yang akan turut menentukan kelancaran kegiatan pondok pesantren. Seperti halnya yang terjadi pada substansi manajemen pendidikan pada umumnya, kegiatan manajemen keuangan pondok pesantren seyogyanya dilakukan melalui proses perencanaan, pengorganisasian, pengarahan, pengkoordinasian, pengawasan atau pengendalian. Beberapa kegiatan manajemen keuangan berupa kegiatan memperoleh dan menetapkan sumber-sumber pendanaan, pemanfaatan dana, pelaporan, pemeriksaan dan pertanggung jawaban. Melalui kegiatan manajemen keuangan maka kebutuhan pendanaan kegiatan pondok pesantren dapat direncanakan, diupayakan pengadaannya, dibukukan secara transparan, dan digunakan untuk membiayai pelaksanaan program pondok pesantren secara efektif dan efisien. Untuk itu tujuan manajemen keuangan pondok pesantren meliputi: (1) Meningkatkan efektivitas dan efisiensi penggunaan keuangan pondok pesantren; (2) Meningkatkan akuntabilitas dan transparansi keuangan pondok pesantren; dan (3) Meminimalkan penyalahgunaan anggaran pondok pesantren.
\end{abstract}

Kata Kunci : Manajemen; Keuangan; dan Pesantren;

\begin{abstract}
The purpose of this research is to find out the description of pesantren financial management. In accordance with the title of the research, the research uses the literature method. The results of the study explained that financial management is an act of financial administration / administration which includes recording, planning, implementation, accountability and reporting. Thus, school financial management can be interpreted as a series of activities regulating school finance from planning, accounting, spending, supervision and accountability of school finances. Financial management of boarding schools is one of the substance of the management of educational institutions that will also determine the smooth operation of boarding schools. As is the case with the substance of education management in general, financial management activities in Islamic boarding schools should be carried out through the processes of planning, organizing, directing, coordinating, supervising or controlling. Some financial management activities take the form of obtaining and determining sources of funding, use of funds, reporting, auditing and accountability. Through financial management activities, the funding needs of Islamic boarding school activities can be planned, procured, transparently recorded, and used to finance the implementation of Islamic boarding school programs effectively and efficiently. For that purpose, the financial management of Islamic boarding schools includes: (1) Improving the effectiveness and efficiency of the use of financial boarding schools; (2) Increasing financial accountability and transparency in Islamic boarding schools; and (3) Minimizing misuse of the boarding school budget.
\end{abstract}

Keywords: Management; Finance; and Islamic Boarding Schools

\section{PENDAHULUAN}

Manajemen keuangan pondok pesantren merupakan salah satu substansi manajamen lembaga pendidikan yang akan turut menentukan kelancaran kegiatan pondok pesantren. Seperti halnya yang terjadi pada substansi manajemen pendidikan pada umumnya, kegiatan 
manajemen keuangan pondok pesantren seyogyanya dilakukan melalui proses perencanaan, pengorganisasian, pengarahan, pengkoordinasian, pengawasan atau pengendalian. Beberapa kegiatan manajemen keuangan berupa kegiatan memperoleh dan menetapkan sumber-sumber pendanaan, pemanfaatan dana, pelaporan, pemeriksaan dan pertanggung jawaban.

Pondok pesantren yang pada awalnya dianggap sebagai lembaga pendidikan alternatif, dewasa ini sudah mengalai kenaikan kasta menjadi lembaga pendidikan solutif dan substantif. Saat ini pondok pesantren dianggap satu-satunya lembaga pendidikan yang tetap eksis membentuk karakter dan kepribadian (personality character) generasi penerus bangsa ini.

\section{METODE PENELITIAN}

Sesuai dengan sifat penelitian, penelitian kepustakaan memiliki beberapa ciri khusus, antara lain; pertama peneliti berhadapan langsung dengan teks atau data angka, bukan dengan lapangan atau saksi mata (eyewitness), berupa kejadian, orang atau benda-benda lain. Kedua, peneliti menggunakan databersifat siap pakai (readymade), artinya peneliti tidak pergi kemana-mana, kecuali hanya berhadapan langsung dengan sumber yang sudah ada di perpustakaan, mencari dan menganalisis data yang terkait dengan penelitian penulis. Ketiga, data diperpustakaan umumnya adalah sumber data sekunder, dalam arti bahwa peneliti memperoleh data dari tangan kedua bukanasli dari tangan pertama dilapangan. Keempat, kondisi data di perpustakaan tidak dibagi oleh ruang dan waktu sehingga dengan mudah peneliti memperolehnya dari berbagai sumber baik yang berasal dari media cetak dan online.

Tulisan ini adalah kajian literatur tentang pengelolaan keuangan pesantren. Sumber kajian adalah berupa buku-buku yang berkenaan dengan dengan tema tersebut dan Jurnal-jurnal ilmiah yang relevan sebagaimana yang telah disebutkan dalam kepustakaan naskah ini. Pembahasan dilakukan berdasarkan metode analisis tematik (thematic Analysis).

Analisis tematik adalahmetode untuk mengidentifikasi, menganalisis dan melaporkanpola-pola atau tema dalam suatudata.Oleh karena itumetode ini dapat mengatur dan menggambarkan data secara mendetail agar dapat menafsirkan berbagaiaspektentang topik penelitian. Prosedur pemrosesan data, data dan informasi yang diperoleh dengan alat yang dipilih dan sumber data atau contoh spesifik masih bersifat perkiraan atau indikatif. Informasi dan data harus diproses sedemikian rupa sehingga dapat digunakan sebagai bahan untuk menjawab pertanyaan penelitian, berdasarkan hasil pengolahan data di atas, peneliti menyimpulkan hasil penelitian deskriptif dengan menjawab pertanyaan penelitian 
dan merangkum semua jawaban dalam kesimpulan yang merangkum masalah penelitian umum.

\section{HASIL DAN PEMBAHASAN}

\section{Tiga Tahap Manajemen Keuangan Pondok Pesantren}

Manajemen keuangan pondok pesantren memiliki tiga tahapan penting yaitu tahap perencanaan (budgeting), tahap pelaksanaan (Akunting) dan tahap penilaian atau evaluasi (Auditing). Ketiga tahapan tersebut harus dilakukan dalam pengelolaan manajemen keuangan pondok pesantren agar keuangan pondok pesantren dan lembaga formal maupun non formal didalamnya sehat, dinamis dan akuntabel.

\section{Penganggaran (budgeting)}

Perencanaan atau Penganggaran (budgeting) merupakan kegiatan atau proses penyusunan anggaran. Budget merupakan rencana operasional yang dinyatakan secara kuantitatif dalam bentuk satuan uang yang digunakan sebagai pedoman dalam pelaksanaan kegiatan-kegiatan lembaga dalam kurun waktu tertentu. Lebih jauh Nanang Fatah menjelaskan dalam menentukan biaya satuan pendidikan terdapat dua pendekatan yaitu pendekatan makro dan pendekatan mikro. Pendekatan makro mendasarkan perhitungan pada keseluruhan jumlah pengeluaran pendidikan yang diterima dari berbagai sumber dana kemudian dibagi jumlah murid.

Morphet (1975) sebagaimana dikutip Mulyasa menjelaskan tentang hal-hal yang perlu diperhatikan dalam penganggaran biaya pendidikan. Pertama, anggaran belanja harus dapat mengganti beberapa peraturan dan prosedur yang tidak efektif sesuai dengan kebutuhan pendidikan; Kedua, merevisi peraturan dan input lain yang relevan, dengan mengembangkan perencanaan sistem yang efektif; dan Ketiga, memonitor dan menilai keluaran pembiayaan secara terus menerus dan berkesinambungan sebagai bahan perencanaan tahap penggaran tahun berikutnya.

Untuk mengefektifkan pembuatan perencanaan keuangan pondok pesantren, maka yang sangat bertanggung jawab sebagai pelaksana ketua pengurus pondok pesantren. Jika lembaga pendidikan formal dibawah pondok pesantren adalah kepala madrasah. Ketua pengurus pondok pesantren dan kepala madrasah harus mampu mengembangkan sejumlah dimensi pengembangan administratif.

Untuk penganggaran minimal ada dua format yang harus dilakukan yang pertama RKA (Rencana Kegiatan Anggaran), biasa disebut RKAS (Rencana Kegiatan Anggaran Sekolah atau RKAPP (Rencana Kegiatan Anggaran Pondok Pesantren); dan RAPB (Rencana 
Anggaran Penerimaan dan Belanja), biasa disebut RAPBS (Rencana Anggaran Penerimaan dan Belanja Sekolah), RAPBM (Rencana Anggaran Penerimaan dan Belanja Madrasah), atau RAPBPP (Rencana Anggaran Penerimaan dan Belanja Pondok Pesantren). Analisis penyususnan RKA dan RAPB memerlukan analisis masa lalu dan lingkungan ekstern (SWOT) yang mencakup kekuatan (strength), kelemahan (weakness), peluang (opportunities) dan ancaman (threats). Pelaksanaan (Akunting)

Akunting adalah bahasa yang digunakan untuk menggambarkan hasil kegiatan ekonomi. Menurut Mulyasa dalam pelaksanaan keuangan dalam garis besarnya dapat dikelompokan ke dalam dua kegiatan, yakni penerimaan dan pengeluaran. Penerimaan dan pengeluaran keuangan pondok pesantren yang diperoleh dari sumber-sumber dana perlu dibukukan berdasarkan prosedur pengelolaan yang selaras dengan kesepakatan yang telah disepakati, baik berupa konsep teoritis maupun peraturan pemerintah. Misalnya penerimaan dana dari SPP (Sahriyah) santri tercatat dalam Buku Penerimaan SPP (Sahriyah) serta ada bukti penerimaan berupa Buku Kartu SPP (Sahriyah) Santri yang dipegang santri. Keduanya dilengkapi dengan Buku Administrasi Penyetoran dan Penerimaan SPP (Sahriyah). Selain itu bila pondok pesantren yang dimaksud memiliki donator tetap maka perlu disediakan Buku Penerimaan Donasi.

Pada proses pelaksanaan selain buku-buku tersebut ada buku utama yang wajib diisi setiap terjadi transaksi, yaitu Buku KAS Umum. Buku KAS Umum ini yang menggambarkan history penerimaan dan pengeluaran dana pondok pesantren. Buku KAS Umum tersebut dilengkapi dengan dokumen Bukti KAS yang berupa kwitansi, faktur, nota, atau catatan administrasi lainnya. Salah satu Bukti KAS yang berupa catatan administrasi ialah Buku Honorarium dan Intensif Asatidz dan Staf (Pegawai).

\section{Evaluasi (Auditing)}

Auditing adalah proses pengumpulan dan pengevaluasian bahan bukti tentang informasi yang dapat diukur mengenai suatu entitas ekonomi yang dilakukan seorang yang kompeten dan independen untuk dapat melaporkan kesesuaian informasi dimaksud dengan kriteria-kriteria yang telah ditetapkan. Sedangkan menurut Mulyasa dalam evaluasi keuangan sekolah, pengawasan merupakan salah satu proses yang harus dilakukan dalam manajemen pembiayaan berbasis sekolah. Pada keuangan manajemen pondok pesantren, ketua pengurus pondok pesantren perlu melakukan pengendalian pengeluaran keuangan pondok pesantren selaras dengan RAPB yang telah ditetapkan.

Menurut Nanang Fattah secara sederhana proses pengawasan terdiri dari tiga kegiatan, yaitu memanatau (monitoring), menilai dan melaporkan. Proses evaluasi ini dilakukan untuk 
dan agar kegiatan-kegiatan yang berkaitan dengan manajemen keuangan berjalan secara efektif dan efisien dan tidak terjadi penyimpangan-penyimpangan dalam prosesnya. Disinilah seorang ketua pengurus pondok pesantren harus memantau dan menilai hasilnya. Ada beberapa jenisjenis Auditing:

a. Audit Laporan Keuangan, Audit laporan keuangan bertujuan menentukan apakah laporan keuangan secara keseluruhan yang merupakan informasi terukur yang akan diverifikasi,telah disajikan sesuai dengan kriteria-kriteria tertentu.

b. Audit Operasional, Audit operasional merupakan penelaahan atas bagian manapun dari prosedur dan metode operasi suatu organisasi untuk menilai efisiensi dan efektitasnya. Umumnya, pada saat selesainya audit operasional, auditor akan memberikan sejumlah saran kepada manajemem untuk memperbaiki jalannya operasi pondok pesantren.

c. Audit Ketaatan, Audit ketaatan bertujuan mempertimbangkan apakah auditi (klien) telah mengikuti prosedur atau aturan tertentu yang telah ditetapkan pihak yang memiliki otoritas lebih tinggi. Suatu audit ketaatan pada lembaga (perusahaan) swasta, dapat termasuk penentuan apakah para pelaksana akuntasi telah mengikuti prosedur yang telah ditetepkan oleh lembaga. Contoh peninjauan tingkat upah,pemeriksaan perjanjian dengan pihak lain (seperti bank/kreditor), dan memenuhi ketentuan hokum yang berlaku.

\section{Problematika Manajemen Keuangan Pondok Pesantren}

Manajemen keuangan pondok pesantren tidak lepas dari berbagai masalah. Di antara masalah-masalah tersebut adalah, lemahnya SDM pengurus, minimnya dana operasional, penyalahgunaan keuangan, membebankan pembiayaan kepada santri, pelaporan keuangan yang penuh manipulasi dan spekulasi, pembelanjaan keuangan yang tidak tepat guna, dan lain sebagainya.

Tak dapat dipungkiri sebagian besar pondok pesantren memiliki keterbatasan SDM yang mumuni dalam manajemen keuangan. Diperparah lagi dengan tidak dilaksanakannya pelatihan tentang manajemen keuangan. Hal ini yang menyebabkan pondok pesantren kesulitan dalam membuat dan menganalisis RAPB dan merealisasikannya sesuai RAPB, serta sulitnya membuat laporan keuangan pondok pesantren yang akutabel dan transparan.

Kurangnya dana operasional pondok pesantren khususnya pondok pesantren yang memiliki santri sedikit, dan minimnya intensif yang diterima para pengurus tidak sedikit menyebabkan terjadinya penyalahgunaan keuangan dan penyalahgunaan kebijakan keuangan.

Penyalahgunaan keuangan memang sudah menjamur di mana-mana, baik instansi swasta maupun negeri, termasuk juga di pondok pesantren. Penyalahgunaan keuangan adalah 
tindakan manipulasi data keuangan dan sengaja melakukan kebijakan spekulatif dalam pembelajaan, termasuk yang paling parah memperkaya diri dengan berbagai cara yang melanggar aturan hukum dan tata tertib pondok pesantren. Walau tidak banyak terjadi di institusi pondok pesantren penyalahgunaan keuangan biasanya sering terjadi dibagian ketua pengurus, bendahara, pimpinan usaha milik pondok pesantren, dan jabatan-jabatan lain yang berkuasa menentukan kebijakan dan atau pememegang langsung uang pondok pesantren.

Mereka memiliki keleluasaan dalam mengendalikan uang. Kebijakankebijakan yang di keluarkan kadang-kadang tidak sesuai dengan apa yang sudah direncanakan dalam Rencana Anggaran Belanja Pondok Pesantren. Sayangnya penyalahgunaan keuangan di pondok pesantren seringkali dibiarkan oleh pengsuh pondok pesantren. Hal ini terjadi di pondok pesantren lebih utama menutupi penyalahgunaan keuangan di pondok pesantren dari khalayak umum karena dianggap aib. Dibiarkan maksudnya tidak sampai dibawa ke pengadilan atau dipolisikan tetapi sebatas dipulangkan dan tidak ada tuntutan untuk mengembalikan uang yang telah dikorupsinya.

Pungutan dana illegal dan usaha-usaha lain yang menghasilkan dana dilakukan tanpa sepengetahuan pengasuh seringkali terjadi dan dilakukan oleh oknum pengurus dan pengelola pondok pesantren. Hal ini sering terjadi karena perputaran keuangan di pondok pesantren cendrung tertutup. Pelaporan keuangan yang akuntabel dan transparan juga terabaikan. Oleh karena itu bagi pengasuh pondok pesantren yang memahami terjadinya potensi penyalahgunaan keuangan mendirikan badan independen audit internal untuk mengawasi realisasi anggaran dan memeriksa laporan keuangan pondok pesantren.

\section{Pengertian Manajemen Keuangan}

Manajemen Keuangan merupakan pengelolaan kegiatan-kegiatan pendidikan yang berkaitan dengan usaha-usaha untuk mendapatkan dana yang dibutuhkan oleh pendidikan dan usaha-usaha bagaiman menggunakan dana tersebut secara efektif dan efisien.

Pembiayaan atau pendanaan pendidikan adalah tanggung jawab bersama antara pemerinttah pusat, pemerintah daerah, dan masyarakat. Tanggung jawab pemerintah pusat dan pemerintah darerah untuk menyediakan anggaran pendidikan berdasarkan prinsip, keadilan, kecukupan dan berkelanjutan.

Pengertian lain dari pembiayaan pendidikan merupakan pembiayaan pendidikan dari jumlah uang yang dihasilkan dan dibelanjakan untuk berbagai keperluan penyelenggaraan pendidikan yang mencangkup: bisyaroh ustad, peningkatan professional ustad, pengadaan dan perbaikan sarana prasarana, pengadaan alat-alat dan dan buku pelajaran, alat tulis kantor (ATK), kegiatanpengembangan keterampilan, kegiatan pengelolaan pendidikan. 


\section{Prisip-prinsip Pengelolaan Keuangan Pendidikan Pondok Pesantren}

Penggunaan anggaran dan keuangan, dari sumber manapun, baik pemerintah ataupun dari masyarakat perlu didasarkan pada prinsip-prinsip umum pengelolaan pengelolaan keuangan sebagai berikut:

a. Hemat, tidak mewah, efisien dan sesuai dengan kebutuhan teknis yang disyaratkan.

b. Terarah dan terkendali sesuai dengan rencana, program / kegiatan.

c. Terbuka dan transparan, dalam pengertian dari dan untuk apa keuangan lembaga tersebut perlu dicatat dan dipertanggungjawabkan serta disertai bukti penggunaannya.

d. Sedapat mungkin menggunakan kemampuan/hasil produksi dalam negeri sejauh dimungkinkan.

\section{Perencanaan dan pelaksanaan pengelolaan keuanga pondok pesantren}

Pihak pesantren bersama komite atau majelis pesantren pada setiap awal tahun anggaran perlu bersama-sama merumuskan rencana anggaran pendapatan dan belanja pondok pesantren (RAPBPP) sebagai acuan bagi pengelola pesantren dalam melaksanakan, manajemen keuangan yang baik.

Anggaran sendiri merupakan rencana yang diformulasikan dalam bentuk rupiah dalam jangka waktu atau periode tertentu, serta alokasi sumber-sumber kepada setiap bagian kegiatan. Anggaran memiliki peran penting di dalam perencanaan, pengendalian dan evaluasi kegiatan yang dilakukan pondok pesantren. Untuk itu setiap penanggung jawab program kegiatan di pesantren harus menjalankan kegiatan sesuai dengan anggaran yang telah ditentukan sebelumnya.

Ada dua bagian pokok anggaran yang harus diperhatikan dalam penyusunan RAPBPP, yaitu :

a. Rencana sumber atau target penerimaan/ pendapatan dalam satu tahun yang bersangkutan, termasuk di dalamnya sumber-sumber keuangan dari :

1. Kontribusi santri

2. Sumbangan dari individu atau organisasi

3. Sumbangan dari pemerintah (Bila Ada)

4. Dari hasil usaha pesantren

b. Rencana penggunaan keuangan dalam satu tahun yang bersangkutan. Semua penggunaan keuangan pesantren dalam satu tahun anggaran perlu direncanakan dengan baik agar kehidupan pesantren dapat berjalan dengan baik juga. Penggunaan keuangan pesantren tersebut menyangkut seluruh pengeluaran yang berkaitan dengan kebutuhan pengelolaan 
pesantren, termasuk untuk dana oprasional harian, pengembangan sarana dan prasarana pesantren, untuk honorarium/gaji/infaq semua petugas/pelaksana di pesantren.

\section{KESIMPULAN}

Manajemen keuangan merupakan tindakan pengurusan/ ketatausahaan keuangan yang meliputi pencatatan, perencanaan, pelaksanaan, pertanggungjawaban dan pelaporan. Dengan demikian, manajemen keuangan sekolah dapat diartikan sebagai rangkaian aktivitas mengatur keuangan sekolah mulai dari perencanaan, pembukuan, pembelanjaan, pengawasan dan pertanggungjawaban keuangan sekolah.

Manajemen keuangan pondok pesantren merupakan salah satu substansi manajamen lembaga pendidikan yang akan turut menentukan kelancaran kegiatan pondok pesantren. Seperti halnya yang terjadi pada substansi manajemen pendidikan pada umumnya, kegiatan manajemen keuangan pondok pesantren seyogyanya dilakukan melalui proses perencanaan, pengorganisasian, pengarahan, pengkoordinasian, pengawasan atau pengendalian. Beberapa kegiatan manajemen keuangan berupa kegiatan memperoleh dan menetapkan sumber-sumber pendanaan, pemanfaatan dana, pelaporan, pemeriksaan dan pertanggung jawaban.

Melalui kegiatan manajemen keuangan maka kebutuhan pendanaan kegiatan pondok pesantren dapat direncanakan, diupayakan pengadaannya, dibukukan secara transparan, dan digunakan untuk membiayai pelaksanaan program pondok pesantren secara efektif dan efisien. Untuk itu tujuan manajemen keuangan pondok pesantren meliputi: (1) Meningkatkan efektivitas dan efisiensi penggunaan keuangan pondok pesantren; (2) Meningkatkan akuntabilitas dan transparansi keuangan pondok pesantren; dan (3) Meminimalkan penyalahgunaan anggaran pondok pesantren.

\section{REFERENSI}

Kahfi, Inal (2019). Anggaran Partisipatif dan Manajemen Pembiayaan Pendidikan. Bandung: Aria Mandiri Group.

Afrizan, Alfian Nurman. 2019. Pengelolaan Keuangan Pesantren. Makalah Mata Kuliah Manajemen Pendidikan Islam. Bandung : UIN Sunan Gunung Djati

Irwan, Arul. 2019. Pengelolaan Keuangan Pesantren. Makalah Mata Kuliah Manajemen Pendidikan Islam. Bandung : UIN Sunan Gunung Djati

Marukirama, Aulia. 2019. Pengelolaan Keuangan Pesantren. Makalah Mata Kuliah Manajemen Pendidikan Islam. Bandung : UIN Sunan Gunung Djati 